Article

\title{
Transcultural Literary Interpretation: Theoretical Reflections with Examples from the Works of Gotthold Ephraim Lessing and Johann Wolfgang Goethe
}

\author{
Steven D. Martinson \\ Department of German Studies, University of Arizona, Tucson, Arizona 85721, USA; \\ martinso@email.arizona.edu \\ Academic Editor: Bernd Fischer \\ Received: 22 April 2016; Accepted: 27 June 2016; Published: 30 July 2016
}

\begin{abstract}
The present contribution explores the topic of literary interpretation from a transcultural perspective. We employ two dramas by Gotthold Ephraim Lessing (Die Juden and Nathan der Weise) and one by Johann Wolfgang Goethe (Iphigenie auf Tauris) as models for the investigation of intercultural and transcultural readings of literary texts. We first consider the epistemologies of Johann Martin Chladenius and Johann Gottfried Herder in order to distinguish between intercultural and transcultural studies. As a field of inquiry, transcultural literary studies does not employ one particular approach or advocate one specific method since it seeks to create new knowledge by opening up literary texts. For the first time, the article differentiates clearly between intercultural and transcultural studies and offers a clearer definition of transcultural spheres or spaces than has been advanced before. The critique of Karl-Josef Kuschel's reading of Lessing's Nathan der Weise opens up the literary-dramatic text to new possibilities. The field does not focus on what cultures do with human beings but with what different human beings do with culture. In sum, the transcultural dimensions of literary texts foster transcultural mentalities. They also have the potential to identify shared experiences and to develop common understandings while respecting the authenticity of difference.
\end{abstract}

Keywords: intercultural; transcultural; transcultural literary interpretation; Johann Martin Chladenius; Johann Gottfried Herder; Gotthold Ephraim Lessing; Nathan der Weise; Johann Wolfgang Goethe; Karl-Josef Kuschel

Im Zuge des kulturtheoretischen Übergangs von 'Inter' zu 'Trans' verlagert sich das kulturwissenschaftliche Interesse also von der althergebrachten Frage, was unterschiedliche Kulturen mit den Menschen tun, zur neuen Frage, was unterschiedliche Menschen mit den Kulturen tun.

(一Friedrich Schulze-Engler ([1], p. 46))

\section{Introduction}

The topic of transculturality raises a number of intriguing questions. First of all, what are transcultural fields and how are they unique? What phenomena do they identify, and what is their potential for cultivating greater understanding ("Verstehen") and even agreement ("Verständigung") among peoples of different cultures worldwide? What is transported from one location to another, and what is left behind, lost, or forgotten? What structures emerge when one culture passes through another and both cultures are transformed? Transcultural studies as a field of inquiry does not employ one particular approach or subscribe to one specific methodology. It is a way of seeing and opening up the world. Transcultural literary interpretation focuses first and foremost on literary texts which are rich sources for the creation of meaning. 
Regarding our procedure on this topic, we first engage in a critical analysis of intercultural and transcultural studies. The second part of the contribution is devoted to the interpretation of several selected literary texts written in German. There is a distinct political component of the concept of the transcultural we are advancing here. Because transcultural fields are receptive to many different cultures, they encourage understanding, rapprochement, and agreement by appreciating not only differences but also commonalities.

\section{Defining the Terms: "Inter-" and "Transcultural"}

The prefixes "inter" and "trans" denote that the words "intercultural" and "transcultural" are not synonymous. In order to clarify the distinction, we turn to theories of knowledge that were first circulating in the German eighteenth century.

\subsection{Intercultural Studies: Epistemology}

Johann Martin Chladenius's theory of knowledge serves as one of the starting points of intercultural studies and Intercultural Germanics. Chladenius's Einleitung zur richtigen Auslegung vernünftiger Reden und Schriften [2] has had a profound effect on hermeneutic studies including the work of the twentieth-century philosopher, Hans-Georg Gadamer (although he was not uncritical of Chladenius, e.g. in his Wahrheit und Methode (Truth and Method, [3], see also [4]). In brief, Chladenius holds that people have different perceptions of the same object. In his Einleitung, Chladenius defined his concept of a "Sehepunkt" (point of view) in terms of space and time, as the location of our eye ("der Ort unseres Auges"), especially as regards our distance from an object ([2], paragraph 309). Every person has his or her own image of something and no other. By virtue of Chladenius's concept of the "Sehepunkt", it appears that no two people share the same point of view. In his masterful study of literary hermeneutics, Introduction to Literary Hermeneutics, Peter Szondi sees that Chladenius's "theory of 'point of view'" relates not to the historicity of the understanding of texts but to the changing ideas about the subject matter treated in the texts [5].

Chladenius believed that it is not only possible but necessary to determine an author's intention in order to fully understand a text. He does not seem to have been aware of the possibility, if not the need, to reflect critically on the reliability of the intention when studying the text. As Hans-Georg Gadamer [Truth and Method] would make clear, when engaging in an exegesis ("Auslegung"; literally: a laying out) of a text, the reader needs to account for one's presuppositions (and biases), accounting for the play of one's own subjectivity which necessarily affects one's reading [3].

The founder of Intercultural Germanics, Alois Wierlacher, adapted Chladenius when describing the Other ("das Fremde") as "das aufgefasste Auge" (the construed eye) ([6], p. 207). Instead of the term "Sehepunkt," Wierlacher employs the word "Blickwinkel" (angle of vision) which, he believes, is an apt signifier for the complex condition and position of the human being to whom belong one's history, ways of thinking, language, everyday knowledge, cultural memory, professional knowledge, knowledge of the world, and one's cultural identity ([6], p. 309). Wierlacher maintains that intercultural phenomena comprise a "Modus kooperativer Selbstaufklärung" since self-enlightenment itself first takes place through the self-distancing in self-conscious awareness of the other ("das Fremde"). Politically, Wierlacher maintains that, as a "Modus der Kulturauseinandersetzung," interculturality conflicts with a narrow, aesthetic "geisteswissenschaftlich" (Gadamerian) concept of culture that has dominated official German political institutions ([6], p. 276, fn. 4). Intercultural Germanics shares with the hermeneuticist Hans-Georg Gadamer the idea that understanding ("Verstehen") means to comprehend things differently. However, Wierlacher does not share Gadamer's conviction that understanding presupposes consent ("ein tragendes Einverständnis"; [6], p. 271). Whereas the primary object of study in intercultural studies is difference, transcultural studies seeks to understand the permeation of two or more cultures and the results of such interaction. Literary texts reflect and comment on these processes in and through their representations. 
Like Wierlacher, Bernd Thum locates "the center of intercultural hermeneutics and research [in] the plurality of, and difference between cultures" [7]. Because Intercultural Germanics focuses on the tensions in opposing themes ("Gegenthemen"), such as between the foreign and the "other" ("das Fremde") and one's own ("das Eigene") ([6], pp. 267-68), the field has a difficult time moving beyond encounter ("Begegnung") and its analyses of difference and conflict. The key objective of Intercultural Germanics is to do justice to the cultural diversity of interests in German and German-speaking countries and the need for transcultural understanding ("Leitziel interkultureller Germanistik ist, der kulturellen Vielfalt des Interesses am Deutschen und den deutschsprachigen Ländern sowie dem Bedarf an transkultureller Verständigung besser gerecht zu werden als es bisherige Modelle von Germanistik vermochten," [8], p. IX). Unlike Transcultural German Studies [9], however, given its roots in the study of German as a Foreign Language, Intercultural Germanics remains focused largely on Germany. Wierlacher's employment of the adjective "transkulturell" in his definition of the key objective of "intercultural" studies should make us pause. Interculturalists have not differentiated clearly between the fields. They may desire better relations between people(s), but their primary focus is on one's own ("das Eigene") versus the other ("das Fremde"). The problem here is not that differences are clarified but that they are reinscribed once such knowledge is attained.

The relation between intercultural and transcultural studies does not constitute a binary opposition between two distinctly different fields of activity since the latter depends on the former for its meaning. One of the practical values of transcultural studies consists in the formation of common understandings and purposes that shared experiences create while respecting the authenticity of differences. Transcultural studies draws upon the knowledge intercultural research establishes but this field of inquiry goes far beyond it. The intercultural flows into the transcultural. The knowledge that is now at one's disposal creates a field of activity in which the permeation and intermixing of cultures of all sorts are understood not in their particularity but in their reciprocal relations.

\subsection{Transcultural German Studies: Epistemology}

Transcultural German Studies draws upon the work of Johann Gottfried Herder. In his essay, Vom Erkennen und Empfinden der menschlichen Seele (On the Cognition and Sensation of the Human Soul), Herder argues that cognition is sparked by the inner state of the powers of sensation, which he terms "der innere Sinn" [10]. For Herder, sense is more basic than sight for the advancement of knowledge. This point is particularly interesting in the light of Herder's determinations about the cultures of far-off places around the world in his monumental work, Ideen zur Philosophie der Geschichte der Menschheit (Ideas on the Philosophy of the History of Humankind, [11]). Whereas hermeneutics renders the unintelligible intelligible, with the aid of the inner sense, the imperceptible is made perceptible. Feeling is the most predominant of all human senses. It is the most fundamental faculty of the soul that collects perceptions ("Vorstellungen") in their external relations. Humanity signals the noble education ("edle Bildung") of the human being which develops finer senses and lends our drives their purpose [12]. In retrospect, because Chladenius valued reason above all else, he did not consider the possibility of shared experience. As Herder's essays suggest, shared experience is cultivated through the "inner sense" that is common to all human beings.

\subsection{Contemporary Understandings of the Transcultural}

Wolfgang Welsch first provided a theoretical framework for transcultural studies. The study of culture, he argued, must take into account the permeation of cultures ("die gegenwärtige Durchdringung der Kulturen", [13], pp. 334-35) and the external networks of cultures ("die externen Vernetzungen der Kulturen"; [13], p. 336). Theoreticians of transcultural studies understand cultures to be multilayered, interactive, and fluid. In fact, the phenomenon of flow is one of the field's main objects of study. Transcultural spheres emerge in the interface between cultural, linguistic, literary, and social phenomena. The intermingling of different cultures in the widest sense form transcultural spheres that move beyond differences and the storm and stress of initial encounters. Transcultural studies' main 
task is to determine the nature, function, and development of shared spaces and places through which process differences are recognized and shared concerns, commonalities, and understanding, if not always agreement, are first realized. The following questions are pivotal: What results when, after initial encounters and conflict, cultures permeate each other? Are not these differences transformed? Moreover, if so, in what ways? The effects of transcultural interaction become apparent when strong contrasts and differences are transformed into new and emerging unities. Such interaction is not only visible in literary texts but also acted out in them. What do we see in them and how does our "inner sense" comprehend them?

Transcultural studies move beyond the encounter and opposition between one's own and another's culture. For the German Americanist Heinz Antor dialogue first makes possible the initial contact between different positionings in hybrid, transcultural spheres ([14], p. 33). As we have proposed, the chief characteristics of transcultural spaces consist in the mutual reciprocity of different cultural elements in which individual cultures retain the authentic forms ([15], p. 75). Friedrich Schulze-Engler has suggested that "transcultural studies do not focus on what culture does with human beings but what different human beings do with culture" (in [14], p. 46). This is a fundamental distinction.

A transcultural sphere, space, or place is ever active. It is revealed not simply by the intersection of two or more cultures. The formation and transformation that inhere in transcultural spheres presupposes that both one's "own" and the "other" change. The reciprocity that the intermixing and permeation of cultures entails also means that the one does not dominate the other. The eighteenth-century German philosopher Immanuel Kant was one of the first to characterize the nature of a transcultural space without naming it. In his Anthropologie in pragmatischer Hinsicht (Anthropology from a Pragmatic Point of View, 1798 [16]), Kant called for thinking differently. A new way of thinking emerges when pluralism opposes egoism. A person no longer attempts to grasp the entire world in one's self but considers oneself to be "simply" ("bloß") a world citizen ("Weltbürger": "Dem Egoism kann nur der Pluralism entgegengesetzt werden, d. i. die Denkungsart: sich nicht als die ganze Welt in seinem Selbst befassend, sondern als einen bloßen Weltbürger zu betrachten und zu verhalten," [16] in [17], p. 92, fn. 35.) On the transcultural plane, a person shares a space in which people begin to "speak" a more common language. In the open spaces of transcultural spheres, human beings recognize their differences and, through their very interaction with each other, begin to understand what they may have in common while at the same time retaining their uniqueness. Proponents of transculturality are not interested in sameness (which is static) but in a distinctiveness and sense of commonality that are perpetually active and creative. Politically, whereas intercultural spaces are often marked by conflict, transcultural spheres are characterized by differentiated unities that promote peace and worldwide cooperation. (As Helge Bonholt and Gerhard Rupp have seen, "The phenomenon of space-time-compression, for example, produces a global, common present and a virtual togetherness, or community of people in the most diverse locations" ([18], p. 166). Like Alois Wierlacher, however, they blur the distinction between intercultural spaces and transcultural spheres.

\subsection{Transcultural Literary Interpretation}

We have suggested before that it is worth considering how cultures of all kinds are tied to, further developed, and transformed through permeating, mixing, and intersecting with other cultures. To what extent does the new research field of Transcultural German Studies produce new ways of interpretation ([15], p. 76, fn. 7)? How does the transcultural study of literary texts function, what can it ascertain, and what insights might it offer into the nature of human interaction and life in general? We here seek to illustrate how transcultural literary interpretation can open up a literary text and show how it can be of interest and even relevance for one's own times. The study of transcultural phenomena can be especially helpful when analyzing the multiple genres/forms that converge in and conjoin literary texts. 
In this paper, we return to eighteenth-century "Germany" to disclose intercultural and transcultural dimensions of three literary texts by two German dramatists. In Gotthold Ephraim Lessing's Die Juden (The Jews) ([19], Vol. 1) we seek to illuminate the operation and limits of the intercultural encounter between a Jewish traveler and a Christian baron. Our second reading explores the realization and operation of transcultural dimensions in Lessing's Nathan der Weise (Nathan the Wise) ([19], Vol. 9) while engaging in critical analyses of major contributions to the current secondary literature. Finally, we interpret Johann Wolfgang Goethe's Iphigenie auf Tauris (Iphigenia in Tauris; [20], Vol. 5) in the light of both intercultural and transcultural literary interpretation arriving at a new reading of this classical German text.

\section{Gotthold Ephraim Lessing's Die Juden}

As Hugh Barr Nisbet has seen, Lessing's The Jews is the first wholly positive portrayal of a Jew in German drama ([21], p. 95). The comedy was the result of considerable reflection on the suppression that Jews were experiencing and continued to suffer. One of Lessing's projects of enlightenment consists in showing that, as true human beings, Jews are capable of good works and possess nobility of soul.

The play begins with a Traveler (a Jew) rescuing a (Christian) Baron from robbers and possibly being killed. The dramatic irony is that we readers/spectators know that the thieves are two servants under the baron's employ. In the course of the action, the two idiotic bandits disclose information that convicts them. Time and again, they voice their prejudice against Jews. The fact that they openly express their bias in the Traveler's presence magnifies the problem of hatred against Jews.

Although the dramatist Lessing exposes the foolishness of discrimination, the intercultural conflict between "nations" (Jews and Christians) remains unresolved in the end. The last exchange between the baron and the Traveler exposes the lack of connection and understanding. BARON: "O wie achtungswürdig wären die Juden, wenn sie alle Ihnen glichen!" (Oh, how dignified Jews would be if they were all like you!) ([19], Vol. 1, p. 487). TRAVELER: “Und wie liebenswürdig die Christen, wenn sie alle Ihre Eigenschaften besäßen!" (And how amiable Christians would be if they all had your attributes!) ([19], Vol. 1, p. 488). The divide between the Christian and the Jew is narrowed but not bridged. The comic effect of The Jews is generated primarily by the servant-thieves whose criminal antics are ridiculed. These stock figures of Saxon comedy, among whom the thief Martin Krumm is the most foolish of the lot, are laughed off the stage. Importantly, already early in his career as a writer of literature, Lessing began to transition from evoking ridicule ("Verlachen") in comedy to cultivating genuine laughter ("Lachen"), good humor. This shift in emphasis led Lessing to write one of his most successful comedies, Minna von Barnhelm. In the serious comedy ("ernsthafte Komödie") audiences begin to reflect critically, also self-critically on their prejudices and insensitivity to one's fellow human beings. In The Jews, Lessing began with the clash between people of different religious and cultural orientations, drawing attention to the inhumanity of prejudice. One of Lessing's greatest contributions to German drama culture is having created literary characters with whom the audience might actually identify. For one thing, the text makes it clear that every country is populated by good and bad people ("daß es unter allen Nationen gute und böse Seelen geben könne"; [19], Vol. 1, p. 461). Even Lessing's main character, the Jewish Traveler, is not without blemish for, as he is given to say, if a Jew deceives, it is usually a Christian who is responsible for having made him do it ([19], Vol. 1, p. 454; see also [22]).

Lessing's drama challenges readers/audiences to take both others ("das Fremde") and themselves ("das Eigene") into consideration when interacting. To this extent, an intercultural reading of the play can be most fruitful for it encourages enlightened critical self-reflection. At the same time, the baron is impressed with the Traveler. He admires the love he has for his fellow man and his magnanimity. Out of gratitude for having rescued him the baron offers his daughter in marriage. But when he discovers that the Traveler is a Jew, he exclaims what a cruel fate it is to discover that his rescuer should be a Jew. The Traveler's servant, Christoph, is stunned. Although his actions can hardly be characterized as Christian-like, Christoph charges that his employer, a Jew, has insulted all of 
Christianity by having him in his employ ([19], Vol. 1, p. 487). The Traveler reminds Christoph as well as the other "Christians" that he cannot expect him to think any better than the rest of the common Christian horde ([19], Vol. 1, p. 487). Reminding his servant that he had rescued him from his miserable situation in Hamburg, Christoph returns the silver box that the thieves had stolen from the Baron, calls the Traveler an honest man, and pledges to stay with him. After all, Christoph notes, a Christian would have given him a kick in the ribs and no box! Later, in Nathan the Wise, Lessing would express his concern about the treatment of Muslims by Christians. As the protagonist's sister, Sittah, states: "Ihr Stolz ist: Christen sein; nicht Menschen" (Your pride is to simply be a Christian, not a human being) Nathan, Act II, Scene 1; [19], Vol. 9, p. 461).

In conclusion, an intercultural reading of Lessing's The Jews discloses the effects of unresolved cultural-religious conflict and the ambivalence that the interactions between "Christians" and the Jewish Traveler create when enmity and distrust prevail.

\section{From Intercultural to Transcultural: Lessing's Nathan der Weise (1779)}

Unlike intercultural encounters, transcultural spaces are not dominated by a specific group or directed by one particular interest. The transcultural sphere is observable in the fluid nature of literary texts. The flow from the intercultural into the transcultural creates new forms, such as the dramatic poem, Lessing's Nathan the Wise. As the borders between people of different cultures and religious persuasions shift and flow, so do the forms that literary texts assume. Through language, literary texts explore, critique, and even reconstruct reality through their representations and the contours of the forms they take.

Literary texts reflect countless examples of hybridity in both the forms they take as well as in the nature of their representations. This is especially true of German literature around 1800 during the "Second Age of Discovery" when the world opened up to frequent sea journeys and continental land expeditions. The pioneering work of Karl S. Guthke in this area is indispensable for our knowledge of cultural-historical developments around 1800, in particular his Die Erfindung der Welt. Globalität und Grenzen in der Kulturgeschichte der Literatur, where he explores the ideas that "die Welt wird global, wird neu erfunden als global" (the world becomes global and is rediscovered as being global) and, importantly, for our study, "[g]lobales Bewußtsein kann sogar den Verhältnissen der nächsten Nähe entspringen, wenn die alltägliche Begegnung mit dem Fremden durchdacht wird" (global consciousness can even stem from everyday local connections when one considers one's everyday encounters with the foreign) ([23], pp. 3-4; see also [24,25]). The "hybridity" that results include the intermingling of "Lebenswelten" inside and outside of Germany and German-speaking countries and cultures, that is, locally, regionally, and globally as well as between and within other languages. Lessing's Nathan der Weise is a mixed, i.e., hybrid form of drama, a dramatic poem ("ein dramatisches Gedicht") as the subtitle of the piece reads. Lessing's classical drama also draws upon several literary forms such as the parable. The play is one of the first to underscore the need for tolerance, ethical right, divine purpose, and deeds. In terms of its content, the work also presents and works with the hybrid character of the multi-, inter-religious family. The play begins with the near-death experience of Recha, the protagonist's adopted daughter, and the growing "love" relationship between her and her rescuer, the Christian knight Templar. A tragedy is averted when it is revealed that they are actually brother and sister. The hybrid nature of the multi- and interreligious family is evident also in Nathan's adoption of a Christian girl and the kinship between Saladin and the Templar. As an adopted daughter, Recha is a link in the expansion of the family.

According to Karl-Josef Kuschel, there is no other work in the history of German literature like this drama which, on the one hand, mirrors the potential for conflict among Judaism, Christianity, and Islamism while, on the other hand, offering a model for reconciliation among Jews, Christians, and Muslims ([26], p. 131). The play is also the first work in the history of German literature to present a Jew, a Christian, and a Muslim on the German stage in the same piece, and positively so ([26], p. 132). Kuschel's main thesis consists in the idea that Lessing pursued his interest in an Islamic humanity 
against strict orthodoxy and that he also intervened in inner-Islamic discourses for the sake of a positive tie between Islam and humanity ("Menschlichkeit") ([26], p. 133). Kuschel points out that Lessing also appreciated the fact that the historical Sultan Saladin was praised not only for his faith and power but also for his tolerance. He argues strongly that Saladin was endowed with reason, morality and humanity not in spite of Islam but through Islam and his faith as a Muslim ([26], p. 134).

In her contribution to the 2006/2007 Lessing Yearbook, Barbara Fischer objected to Kuschel's claim that Lessing's Nathan is pro-Muslim ("ein promuslimisches Stück" ([27], p. 135)) and that the ring parable is an Islamic message is forced. She asks why Lessing did not let Saladin tell the ring parable rather than Nathan. We do not have to wait until the twentieth century to hear from Muhammed Salim Abdullah, upon whom Kuschel draws, in order to answer the question. Lessing was the son of a Lutheran pastor and highly knowledgeable of the Christian protestant tradition. Monika Fick reminded us of the Christian heritage in which Lessing was raised and continued to be actively engaged, in particular the "(Erb)-Sünde-Gnade-Erlösungszusammenhang" of his writings ([28], p. 415f.)). Lessing's vociferous disagreement with Pastor Johann Melchior Goeze (senior pastor of the St. Katharina Church in Hamburg), who Lessing knew personally, in the Anti-Goeze ([19], Vol. 9) and the Axiomata ([19], Vol. 9) confirms that his primary concern was for the messages and practices of the Christian religion. For literary scholars, as Fischer reiterates and Karl S. Guthke had made vividly clear, even given Lessing's considerable knowledge of the region, in Nathan der Weise, the dramatist and theater critic employs "the East" only as a backdrop. In short, the story is still told from a Western perspective ([27], p. 106).

As a follow-up to that discussion, in 2012, Kuschel published the results of his thorough-going investigation of Lessing's references to Islam. (Barbara Fischer was not able to respond. She was killed in 2010 in an automobile accident.) The Catholic theologian advances the idea that Lessing was engaged in a strategic re-evaluation of despised minority religions (including Judaism). Lessing voiced his consternation that people would call Muslims a barbaric folk ([29], p. 23). We should add that with the establishment of university professorial chairs in Orientalist studies in the course of the eighteenth century, the idea of Islam as an anti-Christian, demonic power was questioned by closer study and historical differentiation. Kuschel suggests that, like Christianity and Judaism, Islam is "a natural religion based on reason" ([29], p. 32). As such, it is not a fall from faith but stands in line with the belief in the one, true God found in the Jewish-Christian Bible: "Der Islam ist somit kein Abfall vom Glauben, sondern steht in Kontinuität mit dem in der jüdisch-christlichen Bibel grundgelegten Glauben an den einen und wahren Gott" (Therefore, Islam is not a fall from faith but is contiguous with the belief in the one, true God that is fundamental to the Jewish-Christian Bible) ([29], p. 32).

Given their recognition of, and faith in one God (regula fidei), all three may be seen as natural religions in which reason and revelation inform one's understanding of the Godhead. Perhaps the real point of contention is Kuschel's tendency to conflate the different understandings of God that the three world religions espouse. The strength of Kuschel's understanding consists in his appreciation of Lessing's widening of the view of the Islamic world and his call for tolerance. To be sure, Fischer recognizes that there is "a common tradition revealed in the Torah, the New Testament, and the Qur'an, and all scriptures teach common interreligious ethics" ([27], p. 107). Most importantly, Lessing's drama promotes the common goal of practicing humane humanity, i.e. "Menschlichkeit", which takes place only in the transcultural sphere. We observed that no two people in Die Juden attained this level of interpersonal communication.

Lessing was also concerned with the question of what constitutes truth. In the famous ring parable in Nathan the Wise, none of the three sons possesses the truth. Instead, they are instructed to act as if they owned the true ring. Action is more efficacious than reasoning. Although often overlooked, there is a close tie between the ring parable and the palace parable in Lessing's responses to Pastor Goeze: In Eine Parabel nebst einer kleinen Bitte, und einem eventualen Absagungsschreiben an Herrn Pastor Goeze, in Hamburg (A Parable Along With a Small Request, and Possibly a Rejection Letter to Herr Pastor Goeze, in Hamburg, ([19], Vol. 9, pp. 39-52, a fire breaks out in a palace. The intellectuals gather around to think about what one should do, but they fail to act. Fortunately for them, it is a false alarm and all are 
spared. The message is clear. Action requires both commitment and practical engagement (for a fine discussion of this topic, see [30]).

Kuschel portrays Saladin positively, all-too positively. Doing so leads him to claim that Saladin's (and his sister Sittah's) basic understanding is identical to that of the ideal Jew and ideal Christian ([31], p. 38). To be sure, unlike many of his contemporaries, Lessing did not see in the prophet Mohammed an accomplice of the devil. We agree with Kuschel that, in Nathan the Wise, Lessing created a model for how personal interrelations between peoples of these different religions can be established in the awareness of deeply enmeshed conflicts ([31], p. 39). At first glance, Jews, Christians, and Muslims appear to belong to antagonistic worlds. However, it becomes apparent that a different relationship may lie on the horizon brought about by the realization that they all belong to an original unity and as such share a single community of destiny ([31], p. 41).

Upon examining contemporary performances of Nathan der Weise, Barbara Fischer concluded, and rightly so, that "[b]y propagating Lessing's eighteenth-century interest in the multiplicity of signification at the time of growing transnational communities, global migration, and hybrid identities, directors [of dramas] from diverse cultural and religious backgrounds can help audiences to identify commonalities by —at the same time-pointing out differences" ([27], p. 110). Fischer's conclusion extends from the point of intersection between intercultural and transcultural literary studies.

There is no question that Kuschel's reading of Lessing's dramatic poem is of relevance in our post-9/11 age. His contributions to interreligious dialogue worldwide have been very influential. In the light of our discussion, the "interfaith" relationships that Lessing draws in his dramatic poem operate within a transcultural sphere of activity, which, while fostering tolerance and humanity, retain the authenticity of their most basic religious convictions. But Kuschel's argument regarding the roots of the idea and practice of submission to God in Jewish, Christian, and Islamic religious cultures seems forced. We are to believe that the key word, "Ergebenheit in Gott" (submitting oneself to God) has not only Jewish-Christian but above all ("vor allem") Muslim roots and that by using the adjective, "gottergeben" (surrending oneself to God) Lessing was thinking about the core of Islam ([26], pp. 185 and 186, respectively). The commentators to the ninth volume of the Deutscher Klassiker Verlag's edition of Lessing's works ([19], Vol. 9), Klaus Bohnen and Arno Schilson, refer the reader back to Lessing's theological Auseinandersetzungen with Pastor Goeze. Here, Lessing repeatedly raises the question of the inner truth ("innere Wahrheit") of faith vs. the letter ("Buchstabe") of the Bible. The editors also include Lessing's Reimarus fragments which emphasize the feeling of divine bliss ([19], Vol. 9, p. 1269). In this play, however, it is Nathan, the Jew, and neither the Christian nor the Muslim who conveys the judge's advice in the ring parable. Let the sons practice unbiased love and without prejudice. The strife over which one of them has the genuine of the three rings. If there is rivalry, then it must be in achieving the highest virtues of what the ring symbolizes. Humility, forbearance, and benevolence will aid them in this and submission to the will of God.

However, a common link between the representatives of world religions in this play is not only submission to God but also the practice of love. Kuschel emphasizes the fact that truth and falsehood are determined according to the new criterion of mutual interaction with and for each other before God in the spirit of love ([31], p. 171; see also [32]). It would seem that the transcultural spirit of love is the true source of tolerance for vs. the toleration of differences. From this perspective, Kuschel's main point rings true. The most basic dimension of human existence is submission to God, out of which concrete action in the world is first established and made meaningful; [31], p. 182).

Nathan the Wise moves beyond the encounters of intercultural relations. The permeation and intermixing of Islam with Christianity and Judaism creates a transcultural space in which Christians, Jews, and Muslims embrace each other as members of a larger, extended family while retaining the authenticity of their religious convictions. What is shed in the move from the intercultural to the transcultural is not faith but that letter of the law advanced by institutions of religion. In this drama that law is represented by the Patriarch of the (Eastern) Orthodox Church whose extreme orthodoxy works against interfaith dialogue and the improvement of relations between human beings. 
Kristlieb Adloff's recent contribution to scholarship deserves special attention. For Adloff, the distinctive component of the drama is the space between the Jew, the Christian, and the Muslim. "'Der Christ ist zwischen uns, zwischen Jude und Muslim', sagt Saladin, und dieses 'Zwischen' ist das reizvolle Gelände, in dem sich das Drama bewegt" (The Christian stands between us, between Jew and Muslim,' says Saladin, and this 'between' is the appealing terrain in which the drama moves; [33], p. 124). Adloff argues that the ring parable occurs within this "in-between" space. As such, the dramatic action cannot suspend the different forms of positive religions into a universal religion ([33], p. 124). But they do not really need to since they already converge transcultural spaces.

Although he does not say so, Adloff seems to have embraced Homi Bhabha's idea of "in-betweenness". Bhabha has argued that an intervening space (interstice) emerges in the interface between cultural differences ([34], p. 2). The gaps, or "in-betweenness" of "third" spaces produce forms of culture that interrogate established borders in and between race, gender, and class. Adloff further argues his point, in part in disagreement with Kuschel, as follows:

Der Wahrheitsstreit ist im Ernst zu führen, nicht so sehr als 'interreligiöser Dialog' zwischen den Religionen, dessen unbestreitbarer Nutzen sich auf Abbau von Vorurteilen und die Möglichkeit mitmenschlicher Begegnungen erstreckt, sondern in jenem gerade für das Christentum so bezeichnenden 'Zwischen', wo sich zeigt, was innerhalb der jeweiligen religiösen (bzw. areligiösen) Existenz strittig bleiben muss. Dieser-hoffnungsvolle-Streit erhält Kraft und Glanz von einer Utopie her, von einem Gerichtstag 'über tausend tausend Jahre' (III/7, Z. 23), an dem ein letzter Spruch den Streit beenden wird, kein St. Nimmerstag, wo doch bei Gott tausend Jahre wie ein Tag sind (Ps 90,4). Utopie bedeutet hier nicht, dass die Gegenwart einer imaginären Zukunft geopfert würde.

(The controversy about truth is to be taken seriously, not so much as an 'interreligious dialogue' between religions, whose indisputable benefit encompasses the dismantling of prejudices and the possibility of humane encounters, but in that 'Between' [space] which is so characteristic of Christianity, showing what must remain contentious within religious (and areligious) existence. This-hopeful-controversy contains the power and luster of a utopia, of a judgment day 'over the course of thousands and thousands of years' (III,7, 1. 23), on which a final utterance will end the fight, not a St. Neversday [St. Nimmerstag], as, with God, one day is like a thousand years (Ps. 90, 4). Utopia here does not mean that the present would be sacrificed to an imaginary future).

The maintenance of such narrow spaces continues to activate contestation in the political sphere. In transcultural studies, however, a "third" space is not the in-betweenness but a field of reciprocity and mutual permeation that conjoins opposing walls. In Lessing's Nathan the Wise, the space between the Muslim, the Christian, and the Jew ("Zwischen") is bridged by the mutual embrace and the creation of an extended family. We certainly agree with Adloff that, in Nathan the Wise, we are shown that the bridge to the future is built on a groundwork of friendship ([33], p. 125). The reader/spectator may sense that there is an urgency to building bridges. Nathan expresses this strongly when he beseeches the Templar: "Wir müssen, müssen Freunde sein" (We must be friends) (Act II, Scene 5, 1.532; [19], Vol. 9, p. 533).

To be sure, intercultural studies show and underscore the value and importance of tolerance. Transcultural studies already presuppose and being with acceptance of others. According to Monika Nenon [35], friendship is more than tolerance for an(other) which of itself may not withstand the test of cruel reality. Hence, Nathan works for the Templar's friendship and, in the case of his friend, Saladin, participates in a duel between death and life. In friendship, a bond is achieved, a ring is forged. A transcultural field of activity is evident here as a model for human interaction and the necessary action required to actualize that model. Words are not enough: "Hier brauchts That!" (Here, deeds are required!) ([19], Vol. 9, p. 127). 
In sum, in Nathan the Wise, initially strong contrasts and differences are transformed into new and emerging unities that retain the distinctness (authenticity) of difference, in this case, the different belief structures of Jews, Christians, and Muslims. In the transcultural sphere, all three religions are united in their submission to God and the action that flows from love of humanity. Given its positive reception and recurrent performances worldwide today (as examples, performances of Lessing's Nathan der Weise are planned for 2016 at the Blackbird Theatre in Vancouver, British Columbia, Canada and the Pearl Theatre in New York City), Lessing's Nathan the Wise has become a part of not simply a specific cultural or even collective memory but of worldwide transcultural memory. ${ }^{1}$

\section{Goethe's Iphigenie auf Tauris (1790)}

In his classical drama, Iphigenia in Tauris [20], Johann Wolfgang Goethe, filled the ancient Greek myth of Agamemon and Clytemnestra and the fate of their oldest daughter, Iphigenia, with a new and modern content to explore relations between natives and foreigners.

Early in his work on the intercultural, Wierlacher offered a perceptive analysis of Goethe's dramatic writing. Wierlacher placed the disposition toward foreigners, that is, the intercultural, at the center of his analysis of Goethe's classical drama. Wierlacher begins with line 76 where the protagonist, Iphigenia, asks King Thoas's confidant, Arcas, "Kann uns das Vaterland die Fremde werden?" (Can our fatherland become the foreign?) Wierlacher contends that the absolution of Iphigenia's brother, Orestes, constitutes the turning point in Iphigenia's relationship to the foreign ([37], p. 67). Her fate lies in King Thoas's foreign ("fremde") hand ([20], 1. 1185). Wierlacher also addresses the ties between the language of the drama and the legal discourse of Goethe's place and time regarding the law of nations (Völkerrecht). From his intercultural perspective, Iphigenie treats Thoas as a natural citizen ("Rechtssubjekt"; [37], p. 72). The dramatist sanctions a new custom of universal friendship toward foreigners vs., in a nut shell, xenophobia. Thoas does not refuse Iphigenie's plan to resolve the conflict between the king and her brother and his friend, for "through the acceptance of a valid pledge," as is contained in the Landrecht für die Preußischen Staaten (General Provincial Law of the Prussian States Allgemeines; 1794), a contract is sealed ([37], p. 72)). The fact that the General Provincial Law (which granted legal status to Jews) was not written until well after the writing of Goethe's drama does not seem to bother Wierlacher.

Goethe himself actually went so far to claim that as a member of the highest administrative body in Weimar, he could see even more clearly than Nathan and his creator (Lessing) that the human being must first become a citizen of a country before that person can become a subject of humanity in general ([37], p. 73). However, from a transcultural view, which places human rights (Menschenrechte) over the law of nations, perhaps it is the other way around. Without the "inner sense" of humane humanity advanced by Herder, any such law can only be stated. It is up to people to actualize it and put it into action. Recalling Friedrich Schulze-Engler [1], the field of transcultural studies does not dwell on the question of what culture does with human beings but what different human beings do with culture.

Although agonizing at times, positive social changes occur when Iphigenia is driven by the fates, passes through Taurus, and returns to her homeland, i.e., original culture. What has occurred now that one culture has permeated and intermixed with another culture? Furthermore, what is the result of their interaction? Goethe's classical drama shows that there is a significant shift in individual cultural practices in the direction of humane humanity (Menschlichkeit) and peace. According to ancient law, King Thoas is required to execute strangers who land on the island. Because Iphigenia's brother, Orestes, and his friend, Pylades, have transgressed the cultural-political border of Taurus, they must be killed. There are two important results of the power of Iphigenia's humanity. First, even though Thoas has the right and the intention to marry the (foreign) priestess, Iphigenia refuses and is able to avert a 
forced marriage when she exclaims, "Ich bin so frei geboren wie ein Mann." (I am as free born as any man) ([20], Vol. 5, p. 609, 1. 1858). Second, Iphigenia and Orestes succeed in convincing the king to let them return to their homeland. Iphigenia's high and noble soul ("hohe Seele") and pure childlike trust in a noble man (11. 2143-2145) speaks to Thoas's heart. (For an account of the noble soul and the ethics of politics in Goethe's administrative and literary-dramatic work, see [38]). Iphigenia also asks the king not to simply ban them from his land but, rather, give them his blessing ([20], Vol. 5, pp. 618-19, 11. 2153b-2155a). To be sure, Iphigenia had not wished to be separated from her homeland, "Denn ach mich trennt das Meer von den Geliebten/ Und an dem Ufer steh ich lange Tage,/ Das Land der Griechen mit der Seele suchend" (For, oh, the sea separates me from my loved ones/And I have been standing for many days on the shoreline/Seeking with my soul the land of the Greeks) ([20], Vol. 5, p. 555, 11. 10-12). Spoken, as they are, at the beginning of the drama, the words express the suffering of separation and, now with equal force, apply to the foreign culture. "Leb wohl und reiche mir/Zum Pfand der alten Freundschaft deine Rechte" (Farewell and extend to me/your rights as a pledge of ancient friendship) ([20], Vol. 5, p. 619, 11. 2172-2173). Thoas has the final word, and it is a word of humanity ("Menschlichkeit"): "Lebt wohl!" It is now clear that all three of the Greeks' understanding of a foreign culture has changed. They are now allowed to return to their homeland. Thoas remains at home, but he too has been transformed: "By speaking the truth, Iphigenia not only exposes deception but destabilizes the power constellation. Moral authority usurps political authority and virtuous behavior effects change. The re-formation of society succeeds without recourse to violence" ([38], p. 211, fn. 18). With regard to related scholarship on Goethe's classical drama, Nicolas Boyle sees that it is the human heart that unites the divine world and the world of human moral attitudes. The new "gospel" of humanity is rooted in the human spirit) ([39], p. 450). One of the best contributions on the subject is by T. J. Reed who underscores Iphigenia's ethical integrity and ethical doubt she senses when fleeing with her brother, Orestes, and his friend, Pylades ([40], pp. 211 and 213, respectively).

Given Thoas' experiences, perhaps the law of the land will change and foreigners accepted into Tauris. Perhaps the practice of humanity can effect change in the political public sphere. At least, this was the hope of the German eighteenth century.

\section{Conclusions}

The transcultural dimensions of literary texts cultivate transcultural mentalities. Thinking transculturally promotes a "Lebenspraxis" that includes all "others." By exposing the reader to the presence of transcultural dimensions in literature and having him or her engage in a discussion of it, minds begin to be trained to think transculturally. In the eighteenth century, the activity of "Bildung" (education/cultivation) became an integral part of the perpetual process of enlightenment that Kant theorized and others practiced in the writing and staging of literature in one's own language.

While Lessing's The Jews ends with the gap between the Christian Baron and the Jewish Traveler, the latter drama concludes with the commonality between the three main representatives of Judaism, Islamism, and Christianity regarding submission to God. The authenticity is retained in that each understands the nature of God differently. In both of Lessing's dramas, we observe a physical transcultural space on stage that engages us no longer as spectators but as participants in the action. At the end of Nathan the Wise, the characters embrace each other as members of an extended family. While in this piece recipients consider the relations between world religions, the same kind of structure can adhere in relations between cultures and nations, at which point the transcultural and the transnational share common ground. With respect to Goethe's drama, Iphigenia in Tauris, a transcultural reading discloses how transcultural communication can effect both personal and political change. While the story begins with the storm and stress of crossing borders and its consequence, it ends with reconciliation through mutual understanding. In Goethe's drama, it is not resignation to the will of God but the cultivation and practice of one's own humanity that overcomes the barriers between human beings and political institutions. 
Conflicts of Interest: The author declares no conflict of interest.

\section{References}

1. Friedrich Schulze-Engler. “Von 'Inter' zu 'Trans': Gesellschaftliche, kulturelle und literarische Übergänge." In Inter- und Transkulturelle Studien. Theoretische Grundlagen und interdisziplinäre Praxis. Edited by Heinz Anton. Heidelberg: Carl Winter, 2006, pp. 41-53.

2. Chladenius. Einleitung zur richtigen Auslegung vernünftiger Reden und Schriften. Leipzig: Lanckisch, 1742, Photomechanischer Nachdruck der Ausgabe. Mit einer Einleitung von Lutz Goldsetzer. Düsseldorf: Stern-Verlag Janssen, 1969.

3. Hans-Georg Gadamer. Truth and Method, 2nd ed. Edited by Joel Weinsheimer. Translated by David Marshall. New York: Continuum, 2004, First published as Wahrheit und Methode. Grundzüge einer philosophischen Hermeneutik. Tübingen: J. C. B. Mohr, 1960.

4. Christoph Friedrich. “Johann Martin Chladenius: Die allgemeine Hermeneutik und das Problem der Geschichte." In Klassiker der Hermeneutik. Edited by Ulrich Nassen. Paderborn: Schöningh, 1982, pp. 43-75.

5. Peter Szondi. Introduction to Literary Hermeneutics. Translated by Martha Woodmansee. Foreword by Joel Weinsheimer; New York: Cambridge UP, 1995.

6. Alois Wierlacher. "Interkulturalität. Zur Konzeptualisierung eines Rahmenbegriffs interkultureller Kommunikation aus der Sicht interkultureller Germanistik." Jahrbuch Deutsch als Fremdsprache 26 (2000): 263-87.

7. Bernd Thum. "Auf dem Wege zu einer interkulturellen Germanistik." Jahrbuch Deutsch als Fremdsprache 11 (1985): 334, quoted by H.-J. Schulz. "Identity or Alterity: American Germanistik and Hermeneutics." In Challenges of Germanistik. Traditions and Prospects of an Academic Discipline. Germanistik weltweit? Zu Theorie und Praxis des Disziplinrahmens. Edited by Eitel Timm. Munich: iudicium, 1992, p. 15.

8. Alois Wierlacher, and Andrea Bogner, eds. Handbuch interkulturelle Germanistik. Stuttgart: J. B. Metzler, 2003.

9. Transcultural German Studies/Deutsch als Fremdsprache. Building Bridges/Brücken bauen. Steven D. Martinson, and Renate A. Schulz, eds. Bern: Peter Lang, 2008, [=Jahrbuch für internationale Germanistik (Kongreßberichte A, 94)].

10. Johann Gottfried Herder. Vom Erkennen und Empfinden der menschlichen Seele. Bemerkungen und Träume. Riga: J.F. Hartknoch, 1778.

11. Johann Gottfried Herder. Ideen zur Philosophie der Geschichte der Menschheit. Riga: J.F. Hartknoch, 1784-91.

12. Hans Adler. "Herder's Concept of Humanität." In A Companion to the Works of Johann Gottfried Herder. Edited by Hans Adler and Wulf Köpke. Rochester: Camden House, 2009, pp. 93-116.

13. Wolfgang Welsch. "Transkulturalität. Zwischen Globalisierung und Partikularisierung." Jahrbuch Deutsch als Fremdsprache 26 (2000): 327-51.

14. Heinz Antor, ed. Inter- und Transkulturelle Studien. Theoretische Grandlagen und Interdisziplinäre Praxis. Heidelberg: Carl Winter, 2006.

15. Steven D. Martinson. "Transkulturelle German Studies." In Transcultural German Studies/Deutsch als Fremdsprache. Building Bridges/Brücken bauen. Edited by Steven D. Martinson and Renate Schulz. Bern: Peter Lang, 2009, pp. 72-83.

16. Immanuel Kant. Die Anthropologie in pragmatischer Hinsicht. Königsberg: Friedrich Nicolovius, 1798.

17. John McCarthy. Crossing Boundaries: A Theory and History of Essay Writing in German, 1680-1815. Philadelphia: UP Pennsylvania, 1989.

18. Helge Bonholt, and Gerhard Rupp. "Leseentwicklung im Zeitalter der Globalisierung. Der Beitrag von literarischem Lesen zur interkulturellen Erziehung und zur Ausbildung von Toleranz." In Nathan und seine Erben. Beiträge zur Geschichte des Toleranzgedankens in der Literatur. Festschrift für Martin Bollacher. Edited by Oxana Zielke. with the assistance of Thorsten Meier; Würzburg: Königshausen \& Neumann, 2005, pp. 163-95.

19. Gotthold Ephraim Lessing. Werke und Briefe in zwölf Bänden. Edited by Wilfried Barner, Klaus Bohnen, Gunter E. Grimm, Helmuth Kiesel, Arno Schilson, Jürgen Stenzel and Conrad Wiedemann. Frankfurt: Deutscher Klassiker Verlag, 1985-2003, vol. 3. 
20. Johann Wolfgang Goethe. Iphigenie auf Tauris, Egmont, Torquato Tasso. Dramen 1776-1790, Vol. 5. Sämtliche Werke. Briefe, Tagebücher und Gespräche. 40 vols, Edited by Dieter Borchmeyer. Frankfurt a. M.: Deutscher Klassiker Verlag, 1988.

21. Hugh Barr Nisbet. Gotthold Ephraim Lessing. His Life, Works, and Thought. Oxford: Oxford UP, 2013.

22. Agnes Kornbacher-Meyer. Komödientheorie und Komödienschaffen Gotthold Ephraim Lessings. Berlin: Duncker \& Humboldt, 2003, pp. 216-17.

23. Hans S. Guthke. Die Erfindung der Welt. Globalität und Grenzen in der Kulturgeschichte der Literatur. Tübingen: Francke, 2005.

24. Hans S. Guthke. Lessings Horizonte. Grenzen und Grenzlosigkeit der Toleranz. Göttingen: Wallstein, 2003.

25. Hans S. Guthke. Der Blick in die Fremde. Das Ich und das Andere in der Literatur. Tübingen: Francke, 2000.

26. Karl-Josef Kuschel. "Sei keinem Jud' und Muselmann zum Trotz ein Christ. Gotthold Ephraim Lessing im Spannungsfeld von Judentum, Christen und Islam." In Karl-Josef Kuschel "Gott liebt es sich zu verstecken." Literarische Skizzen von Lessing bis Muschg. Ostfildern: Matthias-Grünewald-Verlag, 2007.

27. Barbara Fischer. “To Each His Nathan: On the Theological Instrumentation of Lessing." Lessing Yearbook 35 (2006/2007): 103-12.

28. Monika Fick. Lessing-Handbuch. Leben-Werk—Wirkung, 2nd ed. Stuttgart: J. P. Metzler, 2004.

29. Karl-Josef Kuschel. "Strategische Aufwertung': Lessings Bilder vom Islam im Zeitalter der Aufklärung." In Islam in der deutschen und türkischen Literatur. Edited by Michael Hofmann. Paderborn: Schöningh, 2012, pp. 19-46.

30. Beate Allert. "About a Burning Building in Eco and Lessing, or: How to Process Messages." Lessing Yearbook XXIV (1997): 57-86.

31. Karl-Josef Kuschel. "Jud, Christ und Muselmann vereinigt"? Lessings Nathan der Weise. Düsseldorf: Patmos, 2004.

32. Daniel Müller Nielaba. Die Wendung zum Bessern. Zur Aufklärung der Toleranz in Gotthold Ephraim Lessings "Nathan der Weise." Würzburg: Königshausen \& Neumann, 2000.

33. Kristlieb Adloff. "'Und doch ist Gott!': Religionskritik und theo-poetische Utopie in Lessings Nathan der Weise." In Lessing im Kontext des europäischen Theaters. Vortragsreihe der Lessing-Akademie (8. März-19. April 2012). Edited by Helmut Berthold. Wolfenbüttel: Lessing-Akademie, 2012, pp. 109-27.

34. Homi Bhabha. The Location of Culture. London: Routledge, 2004.

35. Monika Nenon. "Brücken der Freundschaft in Lessings frühen Komödien." In Proceedings of the Tucson Lessing Conference; Edited by Steven D. Martinson and Richard E. Schade. Lessing Yearbook. 2006/2007, 37, pp. 93-101.

36. James Howell. Alexander von Humboldt and (Trans)Cultural Memory. Ph.D. dissertation, University of Arizona, in progress.

37. Alois Wierlacher. "Ent-Fremdete Fremde-Goethes Iphigenie auf Tauris als Drama des Völkerrechts." In Architektur interkultureller Germanistik. Edited by Alois Wierlacher. Munich: iudicium, 2001, pp. 58-76.

38. Steven D. Martinson. "Toward an Ethical Politics: Johann Wolfgang Goethe, Administrator and Writer or Classical Dramas." Euphorion. Zeitschrift für Literaturgeschichte 109 (2015): 193-234.

39. Nicolas Boyle. Goethe: The Poet and the Age. Volume I: The Poetry of Desire. Oxford: Clarendon Press, 2000.

40. T. J. Reed. "Iphigenie auf Tauris." In Goethe Handbuch. Vol. II: Dramen. Edited by Bernd Witte, Theo Buck, Hans-Dietrich Dahnke, Regine Otto and Peter Schmidt. Stuttgart: J. P Metzler, 1996.

(C) 2016 by the author; licensee MDPI, Basel, Switzerland.This article is an open access article distributed under the terms and conditions of the Creative Commons Attribution (CC-BY) license (http://creativecommons.org/licenses/by/4.0/). 